\title{
Computer Use by School Teachers in Teaching-learning Process
}

\author{
Jyoti Bhalla \\ Department of Educational Studies, Faculty of Education, Jamia Millia Islamia, New Delhi 110025, India \\ Correspondence: Jyoti Bhalla, 322, Pragati Appartments, Punjabi Bagh Club Road, Paschim Vihar, New Delhi \\ 110063, India. Tel: 91-931-144-3210. E-mail: jyoti1507@ hotmail.com
}

Received: March 3, 2013 Accepted: April 2, 2013 Online Published: June 26, 2013

doi:10.11114/jets.v1i2.98 URL: http://dx.doi.org/10.11114/jets.v1i2.98

\begin{abstract}
Developing countries have a responsibility not merely to provide computers for schools, but also to foster a habit of infusing a variety of ways in which computers can be integrated in teaching-learning amongst the end users of these tools. Earlier researches lacked a systematic study of the manner and the extent of computer-use by teachers. The current study examined a comprehensive investigation of 300 Central School teachers' use of computers in India. Towards this end, a questionnaire was constructed that listed essential dimensions for teachers' use of computers: Computer Aided Learning (CAL), Computer Managed Instruction (CMI), and Computer Assisted Instruction (CAI). The findings revealed that teachers often used computers to update subject knowledge and teaching skills, develop lesson plans, prepare additional instructional material, notify relevant information via internet, prepare question banks. They sometimes used computers for showing something in the class, showcasing students' work on school-website, preparing test papers, simulations, games, students' assignments. They had either rarely or never used computers for presenting entire lesson, students' classroom presentations, tutorials, sharing information with parents, publishing homework, giving tests to students - either offline or online, maintaining students' records, and individualized instructions. The analysis indicated that amongst the three categories of computer use, CAL was the most popular category of computer use whereas CAI was the least popular among teachers. The results help to demystify seeming inconsistency and variation with regard to computer use among teachers. The identification of comprehensive ways of computer use empowers stakeholders with vital information and may assist implementation of appropriate measures to fully infuse computers in teaching-learning process.
\end{abstract}

Keywords: computer-use, computer aided learning (CAL), computer managed instruction (CMI), and computer assisted instruction (CAI)

\section{Introduction}

The past two decades have witnessed a dynamic shift in the way the computers have been used as a tool in the teaching-learning process. Today, the trend appears to be towards the creation of courses specifically aimed at computer literacy, as well as towards integrating computer technology in other content areas across the curriculum. Further, computer technology has increasingly been applied towards non-instructional (record keeping, grade averaging, communication, etc.) and pre-instructional (developing materials, researching instructional content, etc.) uses. This great change has brought forth a fresh perspective in the use of computers in the teaching-learning process. The recent advancement in information technology innovations and computer usage is rapidly transforming work culture and teachers cannot escape the fact that today's teaching must provide technology-supported learning. Moreover, links have been made between computer use and constructivist, collaborative, and inquiry-based learning and also pedagogical change (Scrimshaw, 2004). Some researchers suggest that computer technology can overhaul education, serving as a panacea, or as an agent of change. Generally, it is accepted that computers have the potential to enhance teaching and learning (Gordin, Hoadley, Means, Pea, Roschelle, 2000) and provide students with a learning experience that other strategies cannot provide (Wellington, 2005). Therefore, being prepared to adopt and use technology and knowing how that can support student learning must become integral skills in every teacher's professional repertoire.

Governments in most developing countries have responded to the challenge by initiating national programs to introduce computers in education. To better prepare pre-service candidates for teaching in the information age, the International Society for Technology in Education (ISTE) has defined National Educational Technology 
Standards (NETS) (2002) to guide technology integration into teacher education programs. These include dividing the teachers' application of technology in instruction into six categories: technology related understanding, designing of experiences, implementation of curriculum plans, assessment strategies, enhancement of productivity, legal-ethical issues. The United Nations Educational, Scientific and Cultural Organization (UNESCO) implemented Beijing workshop (2003) on Teacher Training in ICT Integration discussed guidelines for developing Competency Based Standards for Teacher Education Curriculum which comprised of core competencies related to pedagogy (new ways of doing things with Information and Communications Technology (ICT), new theories of learning, pedagogical skills: selection, presentation and assessment); technology (related concepts and operations, social, health, legal and ethical issues); and technology-pedagogy integration (ethical and legal use of technology to design effective learning experiences, manage students' learning, improve professional skills, support interaction in learning/social communities). One developing country that is currently pursuing the technological track in education is India. Recognizing the challenge of the "information age", the Indian National Curriculum Framework for School Education, NCERT (National Council of Educational Research and Training) through Curriculum Guide Syllabus for Information Technology in Schools, 2001 addresses at length the question of integration of ICT into schooling, acknowledges the pedagogical rationale behind this integration and brings to the fore its manifold implications. NCERT not only undertakes the development of training materials for teachers and syllabus or instructional materials for students but also holds training/orientation programmes for teachers towards basic ICT skills relevant to school education and developing ability to use ICT-based learning materials for the classroom. The current five year plan also lays emphasis on teacher training in use of computers and teaching through computers. Government of India Ministry of Human Resource Development (MHRD) with its National Mission in Education through ICT has initiated an ICT policy in 2009 wherein the mission is to devise, catalyse, support, sustain ICT and ICT enabled activities and processes in order to improve access, quality and efficiency in the school system. It also promotes networking, research, evaluation and experimentation in ICT tools and ICT enabled practices to utilise the potentials of ICT in school education.

Despite the initiatives, mandates, recommendations by different government organizations, policies, and the ever-increasing use of technology worldwide, it has been observed that computers are not being used effectively by the teachers (other than computer teachers) teaching various subjects like science, maths, languages, commerce, social-sciences, etc. The literature suggests that: (1) Only a few teachers routinely use computers for instructional purposes in different subjects like science, maths, languages, commerce, social-sciences, etc. ; (2) When computers are used, they are generally used for low-level tasks such as presentations, drill, and word processing, by the elementary, secondary and senior-secondary grade students; (3) Computers are not sufficiently integrated across the curriculum. Computers are not being used sufficiently and properly by the school teachers (other than computer teachers) (Becker, 1994; Blankenship, 1998; Dawson, 2008; Drury, 1995; Ely, 1995; Lehtinen \& Sinko, 1999; Mooij \& Smeets, 1999; Omur, 2008; Stratford, 1997; Wallace, 2001). Benzie (1995) indicates that national programs have been of limited success not only because they were formulated in non-educational realms, but also because they were not based on research. Innovation is synonymous with change and the innovation of technology-integrated instruction is an instance of planned, organizational change. Rogers' Innovation Decision Process theory (1995) states that an innovation's diffusion is a process that occurs over time through five stages: Knowledge (of an innovation), Persuasion (forming an attitude towards innovation), Decision (to adopt or reject innovation), Implementation (of the new idea) and Confirmation (of this decision), (pp. 161). In many developing countries where computer is recently introduced in the educational system, researches have mainly focused on the first two stages, that is, on knowledge of an innovation and attitudes about it. The implementation of use of computers in teaching-learning process into the Indian schools has not been guided by research. This has often been the case in most countries across the world. In Rogers' terms (1995), the "initiation stage", which demands information gathering and planning, seems to be missing in this headlong process of technology implementation. In particular, both the researches and the computer technology implementation plans seem to be lacking consideration of the manner and variation in computer use by teachers in teaching-learning process. Does classroom technology result in a fundamentally different brand of instruction? Do teachers tend to use technology as more of an "overlay" upon their present instructional style? With apparent interest and initiative, do teachers continue to engage in meaningful interaction with the computers? Such questions if remaining unanswered may engender unforeseen repercussions for computer integration in schools. As a result, fostering technology usage among individual teachers remains a critical challenge for school administrators, technology advocates and policy makers. Thus, it is beneficial to systematically study various ways of computer use among teachers in order to realize the paradigm shift in the usage of computers with the advent of information technology. The current study was based on this pressing need. The study would help to demystify seeming inconsistency and variation with regard to computer use 
among teachers. The identification of comprehensive ways of computer use would certainly pave the way for policy and decision makers with useful information to aid strategy formulation to fully infuse computer based instructions in teaching-learning process.

\section{Review of the Literature}

Over the past decade technology has been used in a variety of ways and for an array of purposes. As new technologies have emerged they have often times replaced or have been used concurrently with earlier technologies, thus dramatically changing the nature of the way the technology has been used in the classrooms. It is important to note that not all of computer usage in schools during the decade is focused on teaching of basic computer skills, those educators who envisioned a more student centered curriculum and learning environment did attempt to employ computers in different ways among subjects other than the computer subject.

In 1992, the International Association for Evaluation of Educational Attainment (IEA) survey, Computers in American Schools (Becker, 1994), indicated that almost half of middle/junior high and high school mathematics, language, and science teachers and about $70 \%$ of elementary teachers in these areas used computers "at least several times during the year". However, "several times" a year seemed to indicate a failure by teachers to fully infuse computer-based technology into the classroom. Similarly, Drury (1995), in his attempt to implement Information Technology (IT) in schools in Ontario, found that Canadian ministry officials estimated that only 20 percent of the teaching cohort were at least "moderately committed computer users" and even this 20 per cent might not be in favor of a dilution of the traditional curriculum model - "software integrates the curriculum. It can work against a subject approach".

Hadley and Sheingold (1993) found teachers in the United States used computers in multiple ways and reported changes in teaching practice, including: presenting more complex material to students, giving students more individual attention, allowing students to work more independently, and becoming more of a coach and facilitator in the classroom. Glennan and Melmed (1996) examined 5 "technology-rich schools" of Santa Monica, California, in which curriculum and instruction had been changed, and the school days were reorganized to make effective use of technology. These schools were considered to be "representative of the best practices across the nation," and they demonstrated that technology could be used to restructure the learning experience for students and improve learning outcomes. Glennan and Melmed were cautious in their conclusions however and stated: "research has not yet identified a sufficient number of examples of technology-supported whole school reforms to allow us to fully gauge the contributions that educational technology can be reliably expected to make to reform objectives". Harris (2000) revealed that the highest percentage of use of computers and the internet was for preparing instructional materials. Lowest percentage of use of computers and the internet was for instructional use for students. The teachers used word processing primarily for preparing instructional materials, instructing students in the classroom and interactive lab. The second highest use was for web searching.

Wallace (2001) developed a conceptual framework as to how teachers used internet in their teaching and how they used material resources. The results stated that teachers made use of internet by transforming it into a resource which fit into their own teaching methods. Furthermore, Kellenberger and Hendricks (2000) and Martin Ofori-Attah (2005) and identified that the computer use by teachers was divided into three main components namely, for teaching purposes (to impart knowledge, create variety, and to give confidence to teachers), administration purposes (in preparation of job-related materials and to ensure safe-keepings of data and information about students), and personal purposes (to engage teachers' free time in a beneficial and fruitful manner). Omur (2008) in Turkey, investigated the manner and frequency of primary school science teachers' use of computer. Results demonstrated that improving the computer literacy of science teachers seemed to increase science teachers' computer use and consequently increase their integration of computer applications as an instructional tool. Internet, email, and educational software Compact Discs (CDs) were found to be used frequently in the classrooms. Dawson (2008) while examining the extent to which science teachers perceived that their preservice education prepared them to use ICT in their teaching role, found that the most frequent uses of ICT were word processing, internet research, email, and powerpoint while the least frequent uses were palm top computers, web page design, online discussion groups, and virtual excursions. As can be gauged from the above mentioned studies that researchers have employed varying research methods in an attempt to understand the role that technology can and does play in education. Consequently, there are a number of differing lines of research that have been conducted, and many of the lines of inquiry may overlap with others. This has resulted in a large amount of research, but so varied in method and treatment that at times is difficult to categorize. Unfortunately, much of the early research on computer uses in education has ignored the systematic study of ways in which computers can be used by the teachers in teaching-learning process. Studies focused on the most frequent ways of using computers, on the frequency of computer use, on the strength of teachers employing use 
of computers, or on its effect on students' achievement; thus overlooking the conceptual or contextual aspects of ways of computer use in teaching-learning process.

\section{The Study}

Given the importance of the extent of degree and manner of computer use, the purpose of the study was therefore to determine comprehensively the various ways of use of computers in the teaching-learning process.

\subsection{Use of Computers in Teaching-Learning Process}

Use of computers is the incorporation of computer resources and technology-based practices into the daily routines, work, and management of teaching and learning. Taylor (1980) believed that the computer can be used as a tutor to teach students, as a tool for students to use as they would use other educational tools, and as a tutee that students can teach to programme instructions in a computer. Luehrmann (1980) has expressed as three roles of computer: learning about the computer, learning with the computer, and learning from the computer. Later on these three utilizations that Luehrmann has proposed are extended to five: Learning About Computers (computer awareness and computer literacy program or course); Learning From Computers (computers are used either to tutor a student e.g., tutorial software or to provide additional practice on specific skills e.g., drill-and-practice software); Learning With Computers (student makes decisions about how to interact, using the computer, within a simulation or game or problem solving, or uses the computer as a tool to shape information that is already possessed); Learning About Thinking With Computers (computer is used to help students develop new patterns of thinking that may assist them in many different learning situations using programming languages like LOGO/BASIC); Managing Learning With Computers (indirect use of computers in student learning - maintaining student profile, record keeping, diagnostics and remediation, communication). The question of how teachers can best use their computing resources to bring about positive and lasting effects upon students' learning has resulted in the development of two broad sets of curriculum practices (Hodson, 1990; Wellington, 1990). These are: (1) learning about the computer and its impact upon society - i.e. computing studies, (2) learning with, through and from computers - i.e. computers integrated across the curriculum. Today, both sets of curriculum practices command a significant proportion of schools' resources.

\subsection{Ways of Computer Use}

In the present study the term computer means a device which is used for instructional as well as pre-instructional and non-instructional purposes by teachers and students in teaching-learning process. The computer use is defined as ways in which teachers work with computers in the instruction of their students. After undergoing the related literature, the researcher would like to submit that any application of computer for instruction is known as Computer-Based Instruction (CBI) and that CBI is an umbrella term for use of computers in both instruction and management of teaching and learning process, which includes CAL (computer-aided learning), CMI (computer-managed instruction), and CAI (computer-assisted instruction).

\subsubsection{Computer-Aided-Learning (CAL)}

CAL describes an educational environment where a computer is treated as an aid to an overall teaching-learning strategy with other methods and aids such as lectures, demonstrations, projects, textbooks, supplementary books, worksheets, etc. It is used to complement regular teaching. Here, the computer becomes a tool - just like a chalkboard, a calculator, a pen, a chart, a model, a flash card, or a book - that helps teachers teach and helps their students learn. Teachers are resourced with multimedia (CDs or internet) content to explain topics better and make the teaching-learning process joyful, interesting, easy to understand. The computer motivates and caters for different learning abilities. The internet provides far more up-to-date information than text books. Therefore, this mode of instruction employs use of computer in mainly three ways - Whole Class Instruction; Teacher-Directed Student Assignments; Teacher's Self Learning (Figure 1).

\begin{tabular}{ll}
\hline \multicolumn{1}{c}{ Ways } & \multicolumn{1}{c}{ Computer Aided Learning } \\
\hline Whole Class Instruction & $\begin{array}{l}\text { Lessons presented by showing some-thing on the computer in the class; Entire } \\
\text { lesson can also be delivered using computer. } \\
\text { Teacher-Directed }\end{array}$ \\
Student Assignment & $\begin{array}{l}\text { Students use the internet for information searches and computer applications } \\
\text { (word, spreadsheets, presentation, or publisher software) for preparation of project } \\
\text { reports, newsletters, presentations. } \\
\text { Teacher Self Learning } \\
\text { Computer is used to update teacher's subject knowledge and enhance teaching } \\
\text { skills. This includes search on internet, networking with experts, colleagues and } \\
\text { collaboration. }\end{array}$ \\
\hline
\end{tabular}

Figure 1. Computer Aided Learning 


\subsubsection{Computer-Managed-Instruction (CMI)}

Computers are tools that can be used not only to assist teachers as they teach but also to help with classroom management. CMI is an instructional strategy whereby the computer is used to provide learning objectives, learning resources, record keeping, progress tracking, assessment of learner performance, prescribe and control individualized lessons. The student does not necessarily interact with the computer system. The learner may be on-line to take tests. In addition, the computer can diagnose the learning needs of students and prescribe optional sequences of instruction for them. Carlton (2000) provides a list of software designed to function as grade book spreadsheets, databases, question bank, analysis, as examples of CMI. This mode of instruction employs use of computer in management of adjunct functions/instruction-related tasks such as material generation, lesson plan preparation, schedule preparation, attendance monitoring, student's performance assessment, individualized education plans preparation, student reinforcement, communication (Figure 2).

\begin{tabular}{ll}
\hline \multicolumn{1}{c}{ Ways } & \multicolumn{1}{c}{ Computer Managed Instruction } \\
\hline Instructional Material & $\begin{array}{l}\text { Generate material like worksheets, hand-outs, manuals, banners, visuals, } \\
\text { diagrams, for viewing on computer, for projecting, for use in print form. } \\
\text { Computer is used to develop lesson/unit plans. }\end{array}$ \\
$\begin{array}{l}\text { Lesson Plan } \\
\text { Student's Portfolio }\end{array}$ & $\begin{array}{l}\text { Announcements, activities, schedules, Homework are notified via internet. } \\
\text { Students' creative work, achievement and information is disseminated on school }\end{array}$ \\
Communication & $\begin{array}{l}\text { Internet is used to share information with students, professionals, parents. } \\
\text { Student's Performance } \\
\text { Assessment } \\
\text { Computer is used to build question banks, test papers, Students are given tests on } \\
\text { the computer, offline/online. }\end{array}$ \\
Diagnosis-Remediation & $\begin{array}{l}\text { Students' attendance, assignment, grade records are generated and maintained on } \\
\text { computers. } \\
\text { Based on test result, diagnose student's strengths/weaknesses; generate student } \\
\text { profile for the purpose of guidance and counseling. }\end{array}$ \\
\hline
\end{tabular}

Figure 2. Computer Managed Instruction

\subsubsection{Computer-Assisted-Instruction (CAI)}

The term CAI has been used for any program where the computer does the teaching directly. In addition, CAI has often been used relatively synonymously with various other terms such as computer-assisted learning, computer-based learning, computer-enhanced instruction, etc. For the purposes of this study, CAI refers to mode of instruction in which a student directly interacts with a computer and learns through lessons programmed into the computer. Here, computer is used for instructional tasks. The role of the teacher is to provide guidance to students in using this teacher-independent, self-instructional material on a computer at school or at home. The CAI uses instructional software that may broadly be classified in one of the following: tutorial, drill-and-practice, simulation, instructional gaming, and problem solving (Figure 3).

\begin{tabular}{cl}
\hline & \multicolumn{1}{c}{ Computer Assisted Instruction } \\
\hline Ways & \multicolumn{1}{c}{ Description } \\
\hline Tutorial & Present information ask questions, monitor responses, provide feedback, keep records. \\
Drill-and & Present item to work on, provide feedback on correctness and notes on incorrect responses, \\
Practice & summarise results. \\
Simulation & Approximate real-life situations, control expense, access 'inaccessible', perform operations \\
Gaming & Computer acts as competitor, judge, and scorekeeper in motivational format. \\
Problem Solving & Solve basic problems related to calculation, experiment, exploration; maintain database. \\
\hline
\end{tabular}

Figure 3. Computer Assisted Instruction

\section{Methodology}

This was a descriptive study conducted in India. While the state of educational infrastructure, school boards and several other pertinent factors vary drastically across various schools in private, public and state government 
school systems in different regions of the country, Central Schools (run by Kendriya Vidyalaya Sangathan, a premier organization in India administering 981 schools) owing to inherent design, mission, and objectives, maintain considerable uniformity (with common curriculum, academic calendar, performance assessment system) in various establishments across the country and outside also (Moscow, Kathmandu and Tehran). This degree of uniformity is certainly lacking in several other school systems prevalent in the country. Therefore, the target population in this study was Central School teachers in India. Further, the implications of the study could be generalized to design recommendations for formulating policies and strategies at a national and international level. Out of a total of 19 regions in India and abroad, the investigator limited the study to Delhi region only. In this region there are 58 (75 including second shift) Central Schools. A random sample of 20 schools constituted the study sample. From each of the selected school, 15 teachers (teaching various grades and subjects) were selected randomly. Thus, a total number of 300 teachers of Central Schools of National Capital Territory of Delhi constituted the sample of the present study.

Due to dearth in research related to the manner and extent of computer use by teachers, there is a need for designing a comprehensive framework for defining and understanding the use of computers by teachers. This instrument should prescribe essential dimensions of computer use with regard to the extent of ways in which computers can be used in teaching-learning process. Importantly, such an instrument should be readily adaptable to specific national contexts. Once such an instrument is formulated, it could prove to be an indispensable tool in designing measures for professional development of teachers for improving educational quality.

An initial questionnaire was submitted to the experts for face and content validity. An item in the questionnaire was accepted if more than half of the experts provided a rating of more than 3 , on 1 to 5 rating scale (where $1=$ strongly unfavorable to the concept, $2=$ somewhat unfavorable to the concept, $3=$ undecided, $4=$ somewhat favorable to the concept, $5=$ strongly favorable to the concept). Based on their review comments, some items were amended. Two items considered invalid by experts were omitted from the computer-use scale and a quasi-final draft was obtained to be administered on the try-out sample (Table 1).

Table 1. Description related to Validity of Computer Use Scale

\begin{tabular}{lccc}
\hline Computer Use Components & Initial No. of Items & Deleted Items from Initial Draft & Final No. of Items \\
\hline CAL & $6(1-6)$ & Nil & $6(1-6)$ \\
CMI & $19(7-25)$ & Q10, Q19 & $17(7-23)$ \\
CAI & $5(26-30)$ & Nil & $5(24-28)$ \\
Overall Computer Use Scale & 30 & 2 & 28 \\
\hline
\end{tabular}

In order to identify weak, ambiguous, non-functional, or defective items, the quasi-final questionnaire was administered for try-out to a sample of 30 teachers, 10 each from three selected Central Schools of Delhi. The Cronbach's Alpha reliability coefficients on the try-out sample for a set of 28 items of Computer-Use Scale (CAL-6, CMI-17, CAI-5 items) in the quasi-final draft were calculated and presented in Table 2. The Cronbach's Alpha for each of the components and the overall scale was calculated to be: Computer Aided Learning (0.76), Computer Managed Instruction (0.95), Computer Assisted Instruction (0.88) and overall computer use scale (0.96). All values were significant at $\mathrm{p}<0.01$ level. These coefficients indicated a high level of internal consistency for CMI, CAI components and the overall scale, wherein each of the computer use items strongly relate to each other. While the coefficient for the CAL was less than the minimum 0.80 as recommended by Seal and Scott (1992), it suggested that the internal consistency for this component is also adequate.

Table 2. Means, SD, Reliability Coefficients for Computer Use Scale

\begin{tabular}{lcccc}
\hline \multicolumn{1}{c}{ Construct/Component } & N Items & Mean & SD & $\alpha^{*}$ \\
\hline Computer Aided Learning & 6 & 3.17 & 0.58 & 0.76 \\
Computer Managed Instruction & 17 & 3.03 & 0.48 & 0.95 \\
Computer Assisted Instruction & 5 & 2.77 & 0.17 & 0.88 \\
Overall Computer Use Scale & 28 & 3.04 & 0.51 & 0.96 \\
\hline
\end{tabular}

* All significant at $\mathrm{p}<0.01$ level.

The correlation between the scores on the three components and the scale were also computed (Table 3) to see the independent contribution of each component to the overall scale. The components and the scale were significantly correlated with each other. The CAL, CMI and CAI components were highly correlated with the 
scale, with $r=0.66, r=0.96$ and $r=0.72$, respectively. The CAL component was not significantly correlated with the CAI component $(r=0.30)$. The CMI component correlated with the CAL component at $r=0.56$ and CAI component at $r=0.61$. All of the correlations (except the one between CAL and CAI) were significant at $\mathrm{p}<0.01$ level, (two-tailed), showing that the three components have each contributed different information to the global score.

Table 3. Product Moment Correlation Coefficients between the Scores on the Three Components and the Overall Computer Use Scale $(\mathrm{N}=30)$

\begin{tabular}{lcccc}
\hline \multicolumn{1}{c}{ Construct/Component } & CAL & CMI & CAI & Overall \\
\hline Computer Aided Learning & 1 & $0.56^{* *}$ & 0.30 & $0.66^{* *}$ \\
Computer Managed Instruction & $0.56^{* *}$ & 1 & $0.61^{* *}$ & $0.96^{* *}$ \\
Computer Assisted Instruction & 0.30 & $0.61^{* *}$ & 1 & $0.72^{* *}$ \\
Overall Computer Use Scale & $0.66^{* *}$ & $0.96^{* *}$ & $0.72^{* *}$ & 1 \\
\hline
\end{tabular}

* All significant at $\mathrm{p}<0.01$ level.

Thus, after careful considerations, a survey questionnaire (Appendix) was developed by the investigator for collecting data on the variables under study.

$$
\begin{array}{r}
\text { Initial Questionnaire } \\
\text { (Expert:Validity) }
\end{array} \quad \begin{gathered}
\text { Quasi-final Questionnaire } \\
\text { (Try-out:Reliability) }
\end{gathered} \quad \begin{array}{r}
\text { Final Questionnaire } \\
\text { (Data:Analyses) }
\end{array}
$$

The Principals of 20 schools ( 3 schools during the try-out stage and 17 schools during the main stage) were contacted with a copy of the request letter issued by the Assistant Commissioner, Kendriya Vidyalaya Sangathan to seek permission to administer these questionnaires in their schools. After seeking permission from the Principals, the teachers in the staff-room were contacted personally. In order to ensure equitable representation of teachers teaching various grades (elementary, secondary and senior-secondary) and subjects (science, social science, maths, language, commerce, excluding computer teachers), the researcher randomly selected the 15 teachers (from teachers' attendance register) such that preferably a set of 5 teachers was selected from each of the three grades and the set of 5 teachers in a grade collectively represented all the subjects in that grade. A questionnaire was given to each selected teacher personally in the free period. The teachers were given five days to fill-in the questionnaire as per the instructions provided therein and the filled-in questionnaires were collected in person from the teachers on the agreed dates.

\section{Results}

Teachers were asked to respond to 28 statements dealing with the three components of computer use. The items were designed to rate the extent of computer use in Computer Aided Learning CAL (items 1 - 6), Computer Managed Instruction CMI (items 7-23), and Computer Assisted Instruction CAI (items 24-28) on a 5-point scale: $1=$ never (under no circumstances), 2 = rarely (roughly once in a term), 3 = sometimes (approximately once a month), 4 = often (about once a week), $5=$ always (nearly daily/whenever required). The final score (overall computer use) for respondent on scale was sum of the ratings for all of the items. The percentage of respondents in each of these categories of responses was calculated. In addition, the computer use of teachers was represented by a mean score on a 28 item 5-point scale, where 5 (always) represents the maximum score of the scale and 1 (never) represents the minimum score. Table 4 illustrates distribution of mean scores on the computer use scale.

Table 4. Percentage Distribution of Respondents in Use of Computers and Distribution of Mean Scores of Responses on Computer Use Scale

\begin{tabular}{lccccccc}
\hline \multirow{2}{*}{ Computer Use Scale } & Never & Rarely & \multicolumn{1}{c}{ Some-times } & Often & Always & \multirow{2}{*}{ Mean Score } & SD \\
\cline { 2 - 6 } & 1 & 2 & 3 & 4 & 5 & \\
\hline CAL & $0.7 \%$ & $6.7 \%$ & $42.3 \%$ & $43.3 \%$ & $7.0 \%$ & 3.49 & 0.75 \\
CMI & $0.7 \%$ & $21.0 \%$ & $42.0 \%$ & $27.3 \%$ & $9.0 \%$ & 3.23 & 0.91 \\
CAI & $8.7 \%$ & $25.7 \%$ & $38.7 \%$ & $21.3 \%$ & $5.7 \%$ & 2.90 & 1.02 \\
Total Computer Use & $0.3 \%$ & $14.7 \%$ & $48.7 \%$ & $31.3 \%$ & $5.0 \%$ & 3.26 & 0.78 \\
\hline
\end{tabular}


As Table 4 illustrates, on average teachers reported using computers sometimes i.e. approximately once in a month with an overall mean score of $3.26(\mathrm{SD}=0.78)$. The respondents' sometimes use of computers were evident within CAL (mean 3.49), CMI (mean 3.23), and CAI (mean 2.9) also. It can be concluded that, in case of overall computer use, $5 \%$ teachers reported to always use computers, $31.3 \%$ teachers often use computers, $48.7 \%$ sometimes use computers, $14.7 \%$ use computers rarely, and less than one percent of teachers had never used computers in teaching-learning process. The findings revealed that on average, teachers used computers approximately once a month in order to impart CAL, CMI, and CAI in schools.

For the purpose of CAL, the majority of teachers reported use of computers either often (43.3\%) or sometimes (42.3\%), $7 \%$ teachers had always used computers while $6.7 \%$ rarely used computers for whole class instruction (for classroom presentations by teachers); teacher-directed student assignments (for submissions and presentations by students); and teachers' self-learning (for updating teachers' subject knowledge and skills). Again, less than one percent $(0.7 \%)$ had never used computers for CAL.

For CMI, approximately three-fourth of the total number of teachers reported to use computers either sometimes $(42 \%)$ or often $(27.3 \%)$, followed by one fifth of teachers $(21 \%)$, who used computers rarely, and one tenth of teachers $(9 \%)$, who always used computers for instructional material generation, lesson plan preparation, school e-circulars, communication, student's work portfolio, students' grades and performance assessment, record keeping, diagnosis and remediation. Negligible number of teachers $(0.7 \%)$ had never used computers for CMI.

CAI, had the least amount of computer use (mean $=2.90)$ of all the components of computer use. $5.7 \%$ of teachers had always and $38.7 \%$ of teachers had sometimes enabled students to access teacher-independent, self-instructional material like tutorials (to assist concept development), drill and practice exercises (to master concepts), simulations (to experience real life events), educational games (as a reward or motivator), and problem-solving activities (related to calculation, experiment, exploration) on a computer at school or at home. Less than a quarter of teachers $(21.3 \%)$ reported often using computers for CAI. A quarter of teachers rarely used computers and about $8.7 \%$ had never used computers for the purpose of CAI. It was observed that various modes of CAI, in decreasing order of usage, included solving basic problems, playing educational games, simulation, drill-and-practice exercises, and tutorials.

\section{Discussion}

The study investigated the manner and the extent of computer use in teaching-learning process by Central School teachers in India. The literature on computers and constructivist reforms described a variety of activities that were permitted with the use of computers that were not feasible otherwise (Glennan and Melmed, 1996; Hadley and Sheingold, 1993; Psotka and Shute, 1996). Thus, computers can help educators in designing and promoting the teaching and learning (Becker, 1994; Blankenship, 1998; Dawson, 2008; Drury, 1995; Ely, 1995; Sinko and Lehtinen, 1999; Smeets and Mooij, 1999; Stratford, 1997; Wallace, 2001). Researchers Harris (2000); Kellenberger and Hendricks (2000); and Martin and Ofori-Attah (2005) identified that teachers used computers in preparation of job-related material, for safe-keeping of information about students, and to engage free time in a beneficial manner. Internet, e-mail, CDs have been found to be frequently used by teachers (Omur, 2008), and word, internet, e-mail, powerpoint were found to be the most frequent uses of ICT by teachers (Dawson, 2008). The findings from this study also substantiate this. On average teachers reported using computers sometimes i.e. approximately once in a month in order to impart CAL, CMI, and CAI in schools. Thus, Central School teachers in India only sometimes used computers for instructional purposes (whole class instruction, teacher-directed student assignments, and teachers' self-learning, etc.); for pre-instructional purposes (instructional material generation, lesson plan preparation, researching instructional content) and non-instructional purposes (school e-circulars, communication, student's work portfolio, students' grades and performance assessment, record keeping, diagnosis and remediation); and for self-instructional purposes (tutorials, drill and practice exercises, simulations, educational games, and problem-solving activities).

As evident the teachers were using computers for restricted time duration and for performing limited number of tasks, accordingly, teachers seemed not to have sufficiently integrated computers across the curriculum. They often used computers to plan their teaching, to update their knowledge, to prepare additional instructional material. They sometimes used computers for their small classroom presentations, preparing test papers; for students' creative work, assignments, simulations, games. To a smaller extent only a few of them also used computers for their entire classroom presentations, for students' classroom presentations, tutorials, disseminating important information to parents. Most of them have never used computers for publishing homework, students' assessment, record keeping, and individualized instructions. The findings from the study indicate that teachers have already gone through knowledge and persuasion stages (Rogers, 1995) and are probably proceeding to the decision phase, thus they are expected to be using computers in education once computers become more available to them. Therefore, many 
renovations need to be made at the structural level as well as the pedagogical level otherwise, a consistent mismatch will occur between the industrial models of schooling and the information-age teaching-learning devices. Salamon (2002) refers to this mismatch as a "Technological Paradox" resulting from "the consistent tendency of the education system to preserve itself and its practices by the assimilation of new technologies into existing instructional practices" (pp.71-72). Hence, the introduction of computer innovations in education requires equal innovativeness in structural, pedagogical and curriculum approaches.

\section{Conclusion}

Given the recent presence of technology in their schools, developing countries have the responsibility not merely to provide computers for schools, but also to foster a habit of infusing variety of ways in which computers can be integrated in teaching-learning amongst the end users of these tools. As Sheingold (1991, cited in North Central Regional Educational Laboratory, 2003) notes, the challenge of technology integration into education is more human than it is technological. Hence, the study of the ways and extent of computer use becomes indispensable to the technology implementation plans.

The findings of this study may be specific to Central School teachers in India, but their implications are significant to other educators as well. With regard to use of computers in teaching-learning process, on an average more than three-fourth of the teachers were found to use computers (CAL, CMI, and CAI) either often or at least sometimes. About five-to-ten percent teachers reported to always use computers in one of CAL, CMI, and CAI. A few teachers (less than a percent) were found to never use computers at all or use computers only rarely $(15 \%)$. The findings revealed that teachers often used computers to update subject knowledge and teaching skills, develop lesson plans, prepare additional instructional material, notify relevant information via internet, and prepare question banks. Teachers sometimes used computers for showing something in the class, showcasing students' creative work, preparing test papers, simulations, games, students' assignments. Almost half of the teachers indicated that they had either rarely or never used computers for presenting entire lesson, students' presentations, tutorials, sharing information with parents, publishing homework, giving tests to students - either offline or online, maintaining students' attendance/ assignments/grades records, or generating students' profile for the purpose of guidance - counseling. The in-depth analysis indicated that amongst the three categories of computer use, CAL was the most popular category of computer use whereas CAI was the least popular amongst teachers. Thus, teachers more commonly used computers for whole class instruction, teacher-directed student assignments, and teachers' self-learning. They are providing minimal guidance to students in using teacher-independent, self-instructional material on a computer to run tutorials, do drill exercises, perform simulations, play educational games, and solve basic problems.

The amalgamation of computers into education requires equal innovativeness in all the aspects of teaching-learning. Both policy makers and teachers share this policy. Policy-makers should provide additional planning time for teachers to experiment with the variety of ways in which computers can be used in teaching-learning and not limited to specific ways of using them. Such conclusion points to the invariable importance of computer resources for the success of technology initiatives across the world. This also implies that integrating computers in education initiatives should include measures for preparing teachers to use them fully and in a variety of ways in their teaching practice. Teacher's preparations necessitates not merely providing additional training opportunities, but also aiding them in experimenting with compute use before being able to use in teaching and learning.

\section{Acknowledgements}

I thank God for providing me courage to complete this paper. I consider it an honor to accomplish my Ph.D. research work from the Department of Educational Studies, Jamia Millia Islamia, Delhi, India. I would like to express my indebtedness for the participants and experts who have given me their precious time. I am grateful to my guide Prof. Najma Amin for her valuable suggestions. I wish to express my love and gratitude to my beloved husband Mr. Puneet Bhalla and son Master Unnabh Bhalla for their understanding and endless love, through the duration of my work.

\section{References}

Albirini, A. (2006). Teachers' attitudes towards information and communication technologies: the case of Syrian EFL teachers. Computers \& Education, 47, 373-398. http://dx.doi.org/10.1016/j.compedu.2004.10.013

Becker, H. J. (1994). How exemplary computer-using teachers differ from other teachers: Implications for realising the potential of computers in schools. Journal of Research in Computing in Education, 26(3), 291-321. EBSCOhost. 
Blankenship, S. E. (1998). Factors related to computer used by teachers in classroom instruction. Doctoral Dissertation, Virginia Polytechnic Institute and State University. http://scholar.lib.vt.edu/theses/available/etd-32398-14166/

Bruce. (2000). In Roblyer, M. D. (2003). Integrating educational technology into teaching. ( ${ }^{\text {rd }}$ ed.). Columbus, NJ: Merrill Prentice Hall.

Dawson, V. (2008) Use of information communication technology by early career science teachers in Western Australia. International Journal of Science Education, 30, 203-219. http://dx.doi.org/10.1080/09500690601175551

Drury, C. J. (1995). Implementing change in education: the integration of information technology into Irish post-primary schools. M. Sc. Thesis, University of Leiscester, 1990. http://indigo.ie/ cjdrury/thesis/chapter4.html

Ely, D. P. (1995). Technology is the answer! But what was the question? The James P. Curtis Distinguished Lecture, Capstone College of Education Society, University of Alabama. ERIC Service No. ED 381152.

Glennan, T. K., \& Melmed, A. (1996). Fostering the use of educational technology: Elements of a national strategy. Santa Monica, CA. http:// www.rand.org/publications/MR/MR682/contents.html.

Hadley, M., \& Sheingold, K. (1993). Commonalities and distinctive patterns in teachers' integration of computers. American Journal of Education, 101, 281-315. EBSCOhost. http://dx.doi.org/10.1086/444044

Harris, J. M. (2000). Utilization of computer technology by teachers at Carl Schurz High School, A Chicago Public School (Illinois), Dissertation Abstracts International, 61(6), 2268.

Hirsch. (2002). In Roblyer, M. D. (2003). Integrating educational technology into teaching. ( $3^{\text {rd }}$ ed.). Columbus, $\mathrm{OH}$ and Upper Saddle River, NJ: Merrill Prentice Hall.

Hodson, D. (1990). Computer-based education in New Zealand: A time of transition and uncertainty. Journal of Curriculum Studies, 22(1), 67-72. EBSCOhost. http://dx.doi.org/10.1080/0022027900220107

International Society for Technology in Education. (2000). National educational technology standards for teachers. Eugene. http://cnets.iste.org/.

Kellenberger, D. W., \& Hendricks, S. (2000). Predicting teachers' computer use for own needs, teaching and student learning. Journal of Educational Computing Research, 16(1), 53-64. EBSCOhost. http://dx.doi.org/10.2190/RTYK-Y31F-R619-HWVY

Luehrmann, A. (1972). Should the computer teach the student or vice-versa? AFIPS 1972 Spring Joint Computer Conference Proceedings, Vol. 40, AFIPS, Montvale, N.J.; Also appeared in The Computer in the school: tutor, tool, tutee. Taylor, R.P. (1980). 129-135, Teacher College Press. EBSCOhost.

Martin, G., \& Ofori-Attah, K. D. (2005). Internet technology enhanced classroom. http://www2.nesu.edu/nesu/aern/html.

National Policy on Information and Communication Technology (ICT) in School Education. (2009). Department of School Education and Literacy Ministry of Human Resource Development Government of India. http://www.education.nic.in/secedu/ict.pdf

NCERT. (2001). Curriculum Guide syllabus for information technology in schools NCERT. http://www.ncert.nic.in/html/itcurriculum.htm

Roblyer, M. D. (2003). Integrating educational technology into teaching. ( $3^{\text {rd }}$ ed.). Columbus, $\mathrm{OH}$ and Upper Saddle River, NJ: Merrill Prentice Hall.

Rogers. (1995). In Albirini, A. (2006).Teachers' attitudes towards information and communication technologies: the case of Syrian EFL teachers. Computers \& Education, 47, 373-398.

Salamon, D. (2002). Technology and pedagogy: why don't we see the promised revolution? Educational Technology, 42(1), 71-75.

Scrimshaw, P. (2004). Enabling Teachers to Make Successful Use of ICT Coventry: Becta. $\mathrm{http}: / / \mathrm{www}$.becta.org.uk/research/display.cfm?section=1

Seal, J., \& Scott, J. (1992). A brief guide to reliable and valid scale development. Health Promotion Journal, Aus., 2, 41-46 
Sheingold, K., \& Hadley, M. (1990). Accomplished teachers: Integrating computers into the classroom. New York: Center for Technology in Education, Bank Street College of Education. EBSCOhost.

Shute, V. J., \& Psotka, J. (1996). Intelligent tutoring systems: past, present and future. In D. Jonassen (Ed.), Handbook of research on educational communications and technology, Scholastic Publications. http://train.galaxyscientific.com/icaipage/its/its.htm

Sinko, M., \& Lehtinen, E. (1999). The challenge of ICT in Finnish education. Jyvaskyla, Finland: Atena.

Smeets, E., Mooij, T., Bamps, H., Bartolome, A., Lowyck, J., Redmond, D., \& Steffens, K. (1999). The impact of information and communication technology on the teacher. Nijmegen, The Netherlands: ITS. http://webdoc.ubn.kun.nl/anon/i/impaofina.pdf.

Stratford, S. J. (1997). A Review of Computer-Based Model Research in Precollege Science Classrooms. Journal of Computers in Mathematics and Science Teaching, 16(1), 3-23. http://www.editlib.org/p/15204.

Taylor, R. P. (1980). The Computer in the school: tutor, tool, tutee. Teacher College Press.

UNESCO. (2003). Implemented project on training and professional development of teachers/facilitators in the effective use of ICT for improved teaching and learning supported by Japanese funds-in-trust programmes Asia and Pacific regional bureau for education, UNESCO Bangkok, Beijing, China. September 27-29. http://unesdoc.unesco.org/images/0013/001356/135607e.pdf.

Wallace, R. M. (2001). Teaching with the internet: A conceptual framework for understanding the teacher's work and an empirical study of the work of three high school science teachers, Dissertation Abstracts International, 61(10), 3884.

Wellington, J. (2005). Has ICT come of age? Recurring debates on the role of ICT in Education, 1982-2004. Research in Science \& Technological Education, 23(1), 15. EBSCOhost. http://dx.doi.org/10.1080/02635140500068419

Wellington, J. J. (1990). The impact of IT on the school curriculum: Downwards, sideways, backwards and forwards. Journal of Curriculum Studies, 22(1), 56-63. EBSCOhost. http://dx.doi.org/10.1080/0022027900220105

\section{APPENDIX}

\section{Questionnaire to study the computer use of school teachers}

Instructions: Please indicate your response to each of the following statements by circling the number that represents the extent with which you make use of computers. Kindly consider the following explanations when rating your extent of computer use.

$\begin{array}{lll}\text { 1. Never } & : & \text { under no circumstances } \\ \text { 2. Rarely } & : & \text { roughly once in a term } \\ \text { 3. Sometimes } & : & \text { approximately once a month } \\ \text { 4. Often } & : & \text { about once a week } \\ \text { 5. Always } & : & \text { nearly daily/whenever required }\end{array}$

\begin{tabular}{|c|c|c|c|c|c|c|}
\hline \multirow[b]{2}{*}{ \# } & \multirow[b]{2}{*}{ Ways of Computer Use } & \multicolumn{5}{|c|}{ Extent of Use } \\
\hline & & 㐫 & 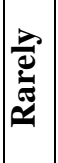 & 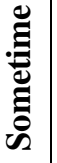 & $\overbrace{0}^{\bar{x}}$ & \\
\hline 1 & Lessons are presented by showing something on a computer in the class & $\mathbf{1}$ & 2 & 3 & 4 & 5 \\
\hline 2 & Entire lesson is delivered using a computer & 1 & 2 & 3 & 4 & 5 \\
\hline 3 & Students are given assignments that require them to use a computer & $\mathbf{1}$ & 2 & 3 & 4 & 5 \\
\hline 4 & Students make classroom presentations using a computer & 1 & $\mathbf{2}$ & 3 & 4 & 5 \\
\hline 5 & Computer is used to update my subject knowledge & 1 & 2 & 3 & 4 & 5 \\
\hline 6 & Computer is used to enhance my teaching skills & $\mathbf{1}$ & 2 & 3 & 4 & 5 \\
\hline 7 & Computer is used to develop lesson/unit plans & 1 & 2 & 3 & 4 & 5 \\
\hline 8 & Computer is used to prepare study schedules & 1 & 2 & 3 & 4 & 5 \\
\hline
\end{tabular}




\begin{tabular}{|c|c|c|c|c|c|c|}
\hline 9 & Computer is used to generate additional instructional material & 1 & 2 & 3 & 4 & 5 \\
\hline 10 & Announcements and relevant information are notified via internet & 1 & 2 & 3 & 4 & 5 \\
\hline 11 & Study material is displayed on internet & 1 & 2 & 3 & 4 & 5 \\
\hline 12 & Homework is published on internet & 1 & 2 & 3 & 4 & 5 \\
\hline 13 & $\begin{array}{l}\text { Students' creative work and achievements related information is disseminated on } \\
\text { school website }\end{array}$ & 1 & 2 & 3 & 4 & 5 \\
\hline \multirow{5}{*}{14} & \multicolumn{6}{|l|}{ Internet is used to share information among } \\
\hline & Colleagues & 1 & 2 & 3 & 4 & 5 \\
\hline & Professionals & 1 & 2 & 3 & 4 & 5 \\
\hline & Students & 1 & 2 & 3 & 4 & 5 \\
\hline & Parents & 1 & 2 & 3 & 4 & 5 \\
\hline 15 & Computer is used to build question banks & 1 & 2 & 3 & 4 & 5 \\
\hline 16 & Computer is used to prepare test papers & 1 & 2 & 3 & 4 & 5 \\
\hline 17 & $\begin{array}{l}\text { Students are given tests on the computer, either offline or online, to assess their } \\
\text { performance }\end{array}$ & 1 & 2 & 3 & 4 & 5 \\
\hline 18 & Students' attendance records are generated on computers & 1 & 2 & 3 & 4 & 5 \\
\hline 19 & Students' assignment records are maintained on computers & 1 & 2 & 3 & 4 & 5 \\
\hline 20 & Students' grades are stored on computers & 1 & 2 & 3 & 4 & 5 \\
\hline 21 & $\begin{array}{l}\text { Computer is used to generate students' profile for the purpose of guidance and } \\
\text { counseling. }\end{array}$ & 1 & 2 & 3 & 4 & 5 \\
\hline 22 & Gifted students get computer based instruction for enrichment & 1 & 2 & 3 & 4 & 5 \\
\hline \multirow[t]{2}{*}{23} & Slow learners get computer based instruction to catch up with the rest of the class & 1 & 2 & 3 & 4 & 5 \\
\hline & \multicolumn{6}{|c|}{$\begin{array}{l}\text { Students are provided guidance in using teacher-independent, self-instructional material on a computer } \\
\text { at school or at home to }\end{array}$} \\
\hline 24 & run tutorials to assist concept development & 1 & 2 & 3 & 4 & 5 \\
\hline 25 & Do drill and practice exercises to master concepts & 1 & 2 & 3 & 4 & 5 \\
\hline 26 & See and perform simulations to experience real life events & 1 & 2 & 3 & 4 & 5 \\
\hline 27 & play educational games on a computer as a reward or motivator & 1 & 2 & 3 & 4 & 5 \\
\hline 28 & solve basic problems related to calculation, experiment, exploration & 1 & 2 & 3 & 4 & 5 \\
\hline
\end{tabular}

\section{Personal Information}

Name of the School:

Name:

Grade (elementary, secondary and senior-secondary):

Curriculum :

(Science/Social Sc./Math/Language /Commerce)

\section{E-mail:}

\section{E-mail:}

Gender:

Class:

(considered for answering to questionnaire)

\section{(c) EY}

This work is licensed under a Creative Commons Attribution 3.0 License. 